Canadian

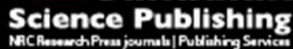

Canadian Geotechnical Journal Revue canadienne de géotechnique

\title{
Soil Restraints on Buried Pipelines Subjected to Reverse Fault Displacement
}

\begin{tabular}{|r|l|}
\hline Journal: & Canadian Geotechnical Journal \\
\hline Manuscript ID & cgj-2016-0564.R1 \\
\hline Manuscript Type: & Article \\
\hline Date Submitted by the Author: & 16 -Feb-2017 \\
\hline Complete List of Authors: & $\begin{array}{l}\text { Wijewickreme, Dharma; University of British Columbia } \\
\text { Monroy, Manuel; Golder Associates Ltd. } \\
\text { Honegger, Douglas; D.G. Honegger Consulting, } \\
\text { Nyman, Douglas; D J Nyman \& Associates }\end{array}$ \\
\hline Keyword: & $\begin{array}{l}\text { Soil pipe interaction, Reverse thrust fault crossings, Earthquake-induced } \\
\text { ground movements, Buried steel pipelines, Soil restraints on pipes }\end{array}$ \\
\hline &
\end{tabular}




\title{
Soil Restraints on Buried Pipelines Subjected to Reverse Fault Displacement
}

\author{
By \\ Dharma Wijewickreme, Ph.D., P.Eng. \\ Professor of Civil Engineering, University of British Columbia \\ Vancouver, B.C., Canada, V6T 1 Z4 \\ Tel.: +1 604-822-5112 \\ Fax: +1 604-822-6901 \\ E-mail: dharmaw@civil.ubc.ca \\ Manuel Monroy, Ph.D., P.Eng. \\ Geotechnical Engineer \\ Golder Associates Ltd. \\ 200 - 2920 Virtual Way \\ Vancouver, British Columbia \\ Canada V5M 0C4 \\ Tel.: +1 6042964200 \\ E-mail: manuel_monroy@golder.com \\ Douglas G. Honegger, \\ President \\ D.G. Honegger Consulting \\ 2690 Shetland Place \\ Arroyo Grande, CA 93420, U.S.A. \\ Tel.: +1-805-473-0856 \\ E-mail: DGHConsult@aol.com \\ Douglas J Nyman, Ph.D., P.E. \\ Principal Engineer \\ D J Nyman \& Associates \\ 350 Horseshoe Ridge $S$ \\ Kerrville, TX 78028, U.S.A. \\ Tel: +1-830-890-5266 \\ E-mail: nymandj@djna.com \\ Manuscript Submitted for \\ Possible Publication as an Article \\ in the Canadian Geotechnical Journal
}

May 02, 2017 


\begin{abstract}
The interaction between a buried pipeline and surrounding soil during large ground displacements is typically simulated using numerical non-linear soil restraint springs aligned in three orthogonal directions with respect to the longitudinal axis of the pipeline. There are only very limited experimental data available to characterize the soil springs for simulating pipelines crossing reverse faults where large oblique soil displacements relative to the pipe could occur. Full-scale model testing was undertaken to evaluate this complex soil-pipe interaction problem. The tests simulated the performance of $\sim 400$-mm diameter (NPS 16) pipe specimens buried in moist sand and crushed limestone trench backfill. The peak normalized oblique soil restraint $\left(\mathrm{N}_{\theta}\right)$ values for oblique pipe movement angles $(\theta)$, when $\theta=0^{\circ}$ (horizontal movement) and $\theta=90^{\circ}$ (vertical movement) estimated based on state-of-practice approaches were in agreement with those from full-scale testing. The value of $\mathrm{N}_{\theta}$ was found to be significantly dependent on the peak friction angle of soil $\left(\phi_{\mathrm{p}}^{\prime}\right)$ when $\theta$ was closer $0^{\circ}$, whereas the $\mathrm{N}_{\theta}$ was less sensitive to $\phi_{\mathrm{p}}^{\prime}$ when $\theta$ was beyond about $35^{\circ}$. The theoretical values of $\mathrm{N}_{\theta}$ based on limit-equilibrium approaches compared well with the experimental findings.
\end{abstract}

Keywords: Soil pipe interaction, Reverse thrust fault crossings, Earthquake-induced ground movements, Buried steel pipelines, Soil restraints on pipes 


\section{Introduction}

Buried pipeline systems, including oil and gas pipelines, form an important part of lifeline infrastructure and major disruption to the performance of these systems can result in undesirable impacts on businesses, economies, or the living conditions of society. Ground displacements related to slope movement, liquefaction-induced lateral spreading, and surface fault movement can lead to the development of significant strains in buried pipelines that are sufficient to cause loss of pressure integrity or interruption of normal service. Pipe burial depth, native and backfill soil properties, and the magnitude and direction of ground displacement directly influence the level of strain imposed on buried pipelines.

The numerical simulation of the response of buried pipelines to ground displacement involves nonlinear finite element analysis conducted in accordance with industry guidelines (e.g., Honegger and Nyman 2004; PRCI 2009). In this approach, the pipeline is modelled with pipe elements, and the soil is modelled with three discrete independent non-linear springs at each node that represent the soil restraint in three orthogonal directions: vertical, axial, and horizontal. The definition of soil restraint as a function of relative displacement between the pipeline and the soil is generally taken to have a constant value after reaching the maximum. Relationships defining soil restraint have been developed mainly based upon the experimental results from tests on anchors and pipes, as well as some analytical approaches and numerical models that have been conducted to study the effect of transverse horizontal and longitudinal axial ground movement on pipes. Except for a few experimental (mostly small-scale), analytical, and numerical studies that have been reported (Audibert and Nyman 1977; Nyman 1984; Trautmann and O'Rourke 1985; Paulin et al. 1998; Guo 2005; Prisco and Galli 2006; Hsu 1996, CCORE 2008, Wijewickreme et al. 2009; Daiyan et al. 2010), comprehensive experimental data to characterize soil restraint versus pipe displacement are relatively scarce in the published technical literature. 
The numerical simulation methodology cited above is generally conservative (or overestimates the resulting strain in the pipeline) in cases for which a reduction in pipe strength is not likely and in cases where the soil restraint is likely to be reduced at large relative displacements between the pipe and the soil. With the exception of situations with a large vertical component of ground displacement, the level of conservatism associated with neglecting a post-peak reduction in soil restraint and assuming independent orthogonal components of soil restraint is typically acceptable. However, for situations where the vertical component of ground displacement is greater than the depth of cover over the pipeline, a substantial reduction in soil restraint is likely as soil sloughs off of the top of the fully-exposed pipeline and as the pipeline breaks through the ground surface. Neglecting this effect is overly conservative and can lead to impractical and excessive design alternatives.

The design of pipelines to withstand the effects of large reverse fault displacements warrants inclusion of improved soil restraint boundary conditions that account for the reduction of vertical soil restraint as the pipe ploughs generally parallel to the fault dip plane (obliquely) through the backfill toward the ground surface. Except for a limited work addressing the problem of pipelines crossing faults (e.g., Hsu et al. 2006; Hsu et al. 2001; Jung et al. 2016; Saiyar et al. 2016; O’Rourke et al. 2016), currently, there is a general absence of public literature relating to oblique soil restraint relationships, particularly relationships that have been validated by appropriate full-scale testing. To alleviate this gap in knowledge, a series of full-scale oblique-displacement pipe-soil interaction model tests have been undertaken at the University of British Columbia (UBC) Advanced Soil Pipe Interaction Research (ASPIRe ${ }^{\mathrm{TM}}$ ) laboratory.

The objective of testing at UBC was to evaluate the mobilization of soil restraints on buried steel pipelines subjected to ground displacements (including oblique displacements as described above) and to determine corresponding pipe-soil displacement relationships. Tests were conducted in two different backfill materials, and the results were used to define pipe-soil interaction relationships for a major international pipeline project. 


\section{Experimental aspects}

A large soil chamber $(2.5 \mathrm{~m} \mathrm{~W} \times 3.8 \mathrm{~m} \mathrm{~L} \times 2.5 \mathrm{~m} \mathrm{H})$ at the UBC-ASPIRe ${ }^{\mathrm{TM}}$ facility as described by (Wijewickreme et al. 2009; Monroy 2013) and shown in Fig. 1 was used to perform large-scale lateral soil restraint tests. The soil chamber allows investigation of the force-displacement relationship of buried pipe configurations subject to axial, lateral, and horizontally oblique loadings. In lateral loading tests, the pipe is aligned parallel to the shorter direction of the chamber, thus requiring the length of tested pipes to be approximately $2.4 \mathrm{~m}$ (see Fig. 2). The outside-wall of the chamber is fitted with a Plexiglas sheet to allow visual observation of the sectional view of the trench configuration, formation of failure wedges, and movement of pipe test specimens during the tests (i.e., note the front visible side in Fig. 1).

The boundary effects associated with the soil chamber during testing had been studied previously by Karimian (2006) during the original design and found to be negligible. The size of the chamber and location of pipe were selected during the design process to allow unhindered formation of displacement zones during lateral soil restraint testing. Displacement zones estimated using analytical and numerical models confirmed the suitability of the selected chamber dimensions. Interface friction between the soil and vertical sidewalls of the box during lateral pipe pullout was minimized by having the back wall lined with stainless steel sheeting and the front wall with Plexiglas material (i.e., material promoting low interface friction with soil). The estimated sidewall friction force was less than $5 \%$ of the total soil loads on the pipe (Karimian 2006).

A plan and lateral view layout of the testing chamber used to mimic the vertical oblique displacement associated with reverse-fault displacement is depicted in Fig. 2. The figure shows the connections made through a sheave system for applying displacements to a buried pipe specimen with a predefined orientation with respect to the horizontal. In particular, the system was designed to subject the pipe 
specimen to displacements oriented in the vertical and horizontal directions as well as at $35^{\circ}$ and $45^{\circ}$ angles to the horizontal, the range in fault dip angle for the reverse faults being investigated.

Tests were carried out using a NPS16 (406-mm outside diameter) steel pipe. Two types of soil were used in the tests: (i) uniformly-graded Fraser River sand; and (ii) uniformly-graded crushed limestone. Tests in sand were necessary to provide a basis for comparison with data from unidirectional horizontal and vertical uplift tests, which, in nearly all cases, have been performed in dry or moist sand soils. Crushed limestone was selected because it was expected to be the only practicable backfill alternative for the construction of a reverse fault crossing in an actual project scenario where neither sand or pea gravel was reasonably available. The details of the soil parameters and grain size curves for the two trench backfill materials are presented in Table 1 and Fig. 3, respectively. The available soil parameters for the wellgraded crushed sand and gravel that was used to represent the pipe trench wall (as described in details in the next section titled "Test Program") are also presented in Table 3 from the viewpoint of completion.

The reported values of effective friction angle $\left(\phi_{p}^{\prime}\right)$ and dilation angle $(\psi)$ for sand (in Table 1) is based on the detailed stress-strain response reported by Karimian (2006) using triaxial tests conducted on Fraser River sand; the triaxial tests were conducted at effective confining stress and sand density ranges that envelope the conditions corresponding to the physical modeling soil-pipe configurations presented in this paper. Due to the relatively large particle size, the tests on limestone were performed using direct shear tests using a $0.3 \mathrm{~m} \times 0.3 \mathrm{~m}$ large shear box available from an industry laboratory. The friction angle value for limestone was estimated based on data available from these tests, again, conducted in alignment with the density and effective confining stress ranges used in the testing program. Due to the strain nonuniformities, the $\psi$ value is not meaningfully obtainable from the direct shear test data. As such, it was back calculated using the data from lateral load tests as per O'Rourke et al. (2008), where the backfill dilation angle is related to the vertical to horizontal ratio of pipe displacement. 
The backfill soil was placed in the soil chamber in $200-\mathrm{mm}$ lifts and mechanically compacted using a static roller to achieve the desired target average soil density. The as-placed compaction densities were measured and controlled using a number of methods: (a) direct measurement using nuclear densometer (Troxler Model 3440 Roadreader ${ }^{\mathrm{TM}}$ Nuclear Moisture/Density Gauge, Troxler Electronic Laboratories, Inc., North Carolina); (b) weighing of soil and moisture content of soil included in metallic bowls of known volume buried in the backfill; (c) density calculations based on overall soil mass placed in the chamber with respect to the final volume of the soil placed in the chamber. After initial placement of soil to a thickness of about $450 \mathrm{~mm}$, the pipe specimen was placed on the soil bed and the filling of the box was continued up to the level corresponding to the desired overburden ratio, $\mathrm{H} / \mathrm{D}$ (where $\mathrm{H}$ is the vertical distance from the pipe centerline to the ground surface, and D is the pipe diameter). The NPS 16 pipe segments used herein were tested with $450 \mathrm{~mm}$ of soil cover above the crown of the pipe $(\mathrm{H} / \mathrm{D}=1.6)$.

A coupling system consisting of end clamps at each end of the pipe with double-ended hook cables was used for pulling the pipe test specimen. Each cable was connected to a loading system consisting of two double-acting hydraulic actuators (capacity $418 \mathrm{kN}$ ) with a load cell mounted on the actuator rod. Bending of the pipe at this scale was assessed to be negligible due to the high section modulus of the steel pipes used in the testing. Two inclinometers and a set of eight string potentiometers (four per loading cable) were utilized to verify and record the displacements applied along the required inclinations during the testing process. In all tests, the total load per unit length on the pipe was determined by adding the load measured from each load cell and then dividing it by the length of the pipe specimen. Symmetry of the pulling system was verified by controlling the difference in indicated readings from each load cell to be less than $5 \%$.

Karimain (2006) and Monroy (2013), through a number of tests conducted on identically prepared specimens at the UBC-ASPIRe ${ }^{\mathrm{TM}}$ facility, have shown similar characteristic response in soil restraint 
versus pipe displacement relationships between respective tests. Their work has demonstrated good test repeatability in terms of specimen preparation and test control, and data acquisition undertaken at the UBC facility.

\section{Test program}

Seven tests conducted using the $\mathrm{ASPIRe}^{\mathrm{TM}}$ soil chamber to represent pipe displacements occurring perpendicular (lateral) to the pipeline alignment, but at different angles $(\theta)$ to the horizontal are presented in this paper: $0^{\circ}$ (horizontal), $35^{\circ}, 45^{\circ}$, and $90^{\circ}$ (vertical). Key test parameters are summarized in Table 2. Tests No. 1 through 3 were conducted using sand backfill around the pipe, and Tests No. 4 through 7 were performed with a crushed limestone backfill.

In the tests where pipes were displaced in the horizontal and vertical directions $\left(\theta=0^{\circ}\right.$ and $90^{\circ}$, respectively), the horizontal and vertical displacement tests were conducted without a simulated trench as these tests were aimed at providing comparison with past investigations by others in sand backfill and a direct comparison between past sand tests and tests in crushed limestone. Tests No. 2, 5, and 6, where the pipe specimen was subject to displacements oriented at $35^{\circ}$ or $45^{\circ}$ inclination to the horizontal, were conducted with a configuration that included a trench with sloped side walls representing the trench design for the reverse fault crossings. The trench wall material was selected so that it would simulate a trench excavated in stiff native soil boundary conditions. Compacted 19-mm minus well-graded crushed sand and gravel (often called as "road mulch" in industry practice) was used in this regard to represent the trench wall. The ability to re-use a "fixed" trench wall for multiple tests provided significant cost efficiency since the backfill material and pipes only needed to be replaced, while the built trench remained unchanged between tests. 
The pipe specimens were loaded in a displacement-controlled manner at a rate of $2.5 \mathrm{~mm} / \mathrm{s}$ in all cases. During oblique tests, the spatial changes in position of each pair of control points located along the left and right pulling cables was calculated from the recordings of the string potentiometers. This data provided the basis to confirm that the pipe remained in an orientation perpendicular to the direction of applied displacement.

A key part in addressing the objectives of this paper is the evaluation of the soil force development on the pipes during the tests. As mentioned previously, Tests No. 2, 5, and 6 were conducted with a configuration simulating a pipe buried in a trench excavated in stiff native soil boundary conditions, whereas the remaining Tests No. 1, 3, 4, and 7 were conducted with the test pipe buried in a uniform backfill. From a test comparison point of view, it would have been ideal if all the tests were conducted under identical burial configurations (i.e., in a configuration with no trenches and only uniform backfill conditions such as those corresponding to the Tests No. 1, 3, 4, and 7); however, undertaking such additional testing was not feasible due to the cost and schedule constraints for this project-directed investigation. From the findings from studies conducted by Monroy (2013) using the UBC ASPIRe ${ }^{\mathrm{TM}}$, as per below, it was possible to demonstrate that the use of data from the tests conducted with the pipe buried in a trench backfill is still applicable for comparison with those performed with uniform backfill conditions. Monroy (2013) conducted a number of inclined lateral pipe displacement tests with $\theta=35^{\circ}$ and $45^{\circ}$ buried in a trench configuration identical to that used for the Tests No. 2, 5, and 6, but with the trench slopes lined with different geotextiles. In some of these tests, the pipe trench was lined using two layers of geotextiles before the backfill was placed around the pipe. When the results from these geotextile-lined tests were compared with those conducted without geotextile lining, it was found that the soil restraint developed in tests with and without geotextile lining were very similar. This observation suggested that the failure wedges in these tests did not extend far enough to mobilize the geotextile 
interface with the lower friction angle; this inference was also corroborated by evidence from the visual observations of failure wedges through the transparent face of the soil chamber. The evidence that the soil-pipe response is not affected by the presence of the trench in these inclined lateral pipe displacement tests (i.e., where the pipes were obliquely pulled with $\theta=35^{\circ}$ and $45^{\circ}$ ), suggested that the data from Tests No. 2, 5, and 6 (with the presence of the trench) would justifiably qualify for use along with the results from Tests No. 1, 3, 4, and 7 in the present assessment.

Test results from this work are presented in terms of normalized values of oblique lateral soil restraint in the direction of displacement, $\mathrm{N}_{\theta}$ as per below:

$$
\mathrm{N}_{\theta}=\mathrm{P}_{\theta} /(\gamma \cdot \mathrm{D} \cdot \mathrm{H} \cdot \mathrm{L})
$$

where $P_{\theta}$ is the measured lateral load on the pipe due to oblique pipe movement, $\gamma$ is the effective unit weight of the backfill, $\mathrm{D}$ is the pipe diameter, $\mathrm{H}$ is the height of soil over the pipe spring line, and $\mathrm{L}$ is the pipe length. This approach is identical to the approach to define $\mathrm{N}_{\mathrm{qh}}$ and $\mathrm{N}_{\mathrm{qv}}$, commonly defined normalized lateral soil constraints in ASCE (1984) and PRCI (2009) as indicated below for $\theta=0^{\circ}$ (horizontal pipe movement) and $\theta=90^{\circ}$ (vertical pipe movement), respectively.

$$
\begin{aligned}
& \mathrm{N}_{\mathrm{qh}}=\mathrm{N}_{0^{\circ}}=\mathrm{P}_{0^{\circ}} /(\gamma \cdot \mathrm{D} \cdot \mathrm{H} \cdot \mathrm{L}) \\
& \mathrm{N}_{\mathrm{qv}}=\mathrm{N}_{90^{\circ}}=\mathrm{P}_{90^{\circ}} /(\gamma \cdot \mathrm{D} \cdot \mathrm{H} \cdot \mathrm{L})
\end{aligned}
$$

\section{Results of soil restraint tests for pipes buried in sand backfill}

The $\mathrm{N}_{\theta}$ versus pipe displacement responses observed for three tests conducted with an NPS16 pipe specimen buried in moist sand with an overburden ratio (H/D) of 1.6, and with pipe displacements occurring at different angles $(\theta)$ to the horizontal (Test No. 1 with $\theta=0^{\circ}$; Test No. 2 with $\theta=45^{\circ}$; and Test No. 3 with $\theta=90^{\circ}$ ) are shown in Figs. 4(a) through 4(c). In all tests, the observed soil-pipe 
interaction is characterized by an initially stiff response followed by a gradual softening prior to $\mathrm{N}_{\theta}$ reaching a maximum plateau value.

For the Test No. 1, the value of $\mathrm{N}_{0^{\circ}}\left(=\mathrm{N}_{\mathrm{qh}}\right)$ reached a maximum value of about $7.8(32.9 \mathrm{kN} / \mathrm{m})$ when the pipe displacement was around $0.25 \mathrm{D}$. Due to test set up limitations during this test, some interruptions to the loading process were necessary, in turn, leading to the "loading and unloading" pulses that can be seen in Fig. 4(a). However, the observed soil restraint upon reloading still seems consistent with the curve arising from the uninterrupted part of the test. Although not repeated herein for brevity, similar results have been observed in tests conducted using the same facility by Karimian (2006) from two identical tests conducted at $\theta=0^{\circ}$ on NPS 18 pipe specimens buried in moist sand with $H / D=1.9$.

The variation of normalized oblique lateral soil restraint $\mathrm{N}_{45^{\circ}}$ versus pipe displacement for Test No. 2 conducted in sand backfill is shown in Fig. 4(b). A vertical oblique pulling displacement of about 1.3D was applied to the pipe specimen. In the test, there was continuous increase of soil restraint during the test until a peak oblique lateral soil restraint of $14 \mathrm{kN} / \mathrm{m}\left(\mathrm{N}_{45^{\circ}}\right.$ of about 3.0) was mobilized at displacement of about $0.1 \mathrm{D}$. After the peak soil restraint was reached, a decrease of loading with continued displacement occurred at a fairly constant rate to the end of the test. A minimum $\mathrm{N}_{45^{\circ}}$ value of 1.8 was reached at a vertical oblique pipe displacement of $1.3 \mathrm{D}$.

Variation of normalized vertical soil restraint, $\mathrm{N}_{90^{\circ}}\left(=\mathrm{N}_{\mathrm{qv}}\right)$, versus vertical pipe displacement for Test No. 3 is shown in Fig. 4(c). A vertical pulling displacement of approximately 1.0D was applied to the pipe. The relationship between $\mathrm{N}_{90^{\circ}}$ and pipe displacement is characterized by a continuous rise in vertical soil restraint during the initial part of the test until the peak value of $\mathrm{N}_{90^{\circ}}$ of just over 2 is fully mobilized at a displacement of approximately $0.05 \mathrm{D}$. The value of $\mathrm{N}_{90^{\circ}}$ drops to approximately 1.7 at a displacement of approximately $0.1 \mathrm{D}$ and then decreases uniformly to an $\mathrm{N}_{90^{\circ}}$ value of approximately 0.8 at the end of the 
test.

\section{Results of soil restraint tests for pipes buried in crushed limestone}

Normalized purely horizontal soil restraint-displacement response, $\mathrm{N}_{0^{\circ}}$, for Test No. 4 is shown in Fig. 4(d). From the results presented in Fig. 4(d), it can be observed that the peak normalized soil restraint factor is approximately 12 at a displacement of approximately $0.1 \mathrm{D}$, followed by a drop in lateral soil restraint to near-constant post-peak level of restraint corresponding to an $\mathrm{N}_{0^{\circ}}$ of 10 for values of displacement greater than about $0.2 \mathrm{D}$.

Variation of $\mathrm{N}_{35^{\circ}}$ with pipe displacement for Test No. 5 is shown in Fig. 4(e). As can be observed from the plot in Fig. 4(e), a continuous increase in soil restraint, similar to Test No. 4, occurred during the initial part of the test until an $\mathrm{N}_{35^{\circ}}$ value of about 3.8 was reached at a displacement of $0.18 \mathrm{D}$. The soil restraint decreased at a near-uniform rate after reaching the peak restraint, reaching an $\mathrm{N}_{35^{\circ}}$ value of 1.9 at a vertical oblique displacement of $1.2 \mathrm{D}$ at the end of the test.

The observed $\mathrm{N}_{45^{\circ}}$ versus pipe displacement relationship for Test No. 6 is shown in Fig. 4(f). As with Test No. 5, a continuous rise of soil restraint occurred during the initial part until a normalized vertical oblique soil restraint factor, $\mathrm{N}_{45^{\circ}}$, of about 2.9 was reached at a displacement of about $0.15 \mathrm{D}$. Once the peak value of $\mathrm{N}_{45^{\circ}}$ was reached, the soil restraint continuously decreased to an $\mathrm{N}_{45^{\circ}}$ value of about 1.4 when the test was terminated.

Variation of normalized vertical soil restraint $\mathrm{N}_{90^{\circ}}\left(=\mathrm{N}_{\mathrm{qv}}\right)$ versus displacement for Test No. 7 is shown in Fig. 4(g). A vertical pulling displacement of approximately $0.8 \mathrm{D}$ was applied to the pipe specimen. The 
soil-pipe interaction behavior under vertical displacement shows a large decrease in soil restraint at displacements beyond that at which the maximum restraint occurs. The peak value of $\mathrm{N}_{90^{\circ}}$ for Test No. 7 was about 2.3 and occurred at a value of displacement of approximately 0.1D. At a displacement of 0.2D, the vertical soil restraint had reduced to $50 \%$ of the peak value. For displacements greater than $0.2 \mathrm{D}$, the vertical soil restraint continued to decrease to a value of about $25 \%$ of the peak value at a displacement of 0.8D.

\section{Discussion - results of soil restraint tests}

A summary of the results obtained during this experimental program is given in the Table 3 . Firstly, the difference in the observed levels of peak soil restraint for the two materials can be attributed to the differences in their frictional properties (see Table 3 for the significant difference in the friction angles).

A comparison of the $\mathrm{N}_{0^{\circ}}$ and $\mathrm{N}_{90^{\circ}}$ values (i.e., $\mathrm{N}_{\mathrm{qh}}$ and $\mathrm{N}_{\mathrm{qv}}$, repectively) obtained from the tests in different backfills with those derived from the PRCI (2009) approach, based upon Yimsiri et al. (2004), is presented in Table 4. The estimation of $\mathrm{N}_{0^{\circ}}$ and $\mathrm{N}_{90^{\circ}}$ values corresponding to the case with crushed limestone backfill required extrapolation since the PRCI method does not provide the predictions for backfills having $\phi_{\mathrm{p}}^{\prime}$ values greater than $45^{\circ}$. The peak $\mathrm{N}_{0^{\circ}}$ and $\mathrm{N}_{90^{\circ}}$ values estimated based on PRCI (2009) using the $\phi_{\mathrm{p}}^{\prime}$ values obtained from material-specific laboratory element testing are in reasonable agreement with those directly measured from full-scale soil-pipe interaction chamber testing. The recommended values of displacement to reach maximum $\mathrm{N}_{0^{\circ}}$ in PRCI guidelines are 0.08 for an $\mathrm{H} / \mathrm{D}$ value of 1.6. As indicated in the load-displacement plots in Fig. 4, the pipes tested at H/D ratio 1.6 had displacements at maximum $\mathrm{N}_{0^{\circ}}$ ranging from $0.08 \mathrm{D}$ to $0.25 \mathrm{D}$. It appears that the determination of displacement at maximum $\mathrm{N}_{0^{\circ}}$ is not simply a function of $\mathrm{H} / \mathrm{D}$ ratio, but is dependent on other factors such as the backfill soil gradation and material density. A lower value of displacement to mobilize the maximum soil restraint results in a stiffer soil restraint characterization, which is generally conservative 
for the purposes of evaluating pipeline response to lateral ground displacements as it leads to a higher rate of pipe deformation with ground displacement.

The rates of change in vertical soil restraint with pipe displacements after peak may be related to the particle size distribution of the different backfill materials. The rate of post-peak load reduction (with respect to pipe displacement) for tests in sand is less than that for tests in limestone with equal geometric conditions. The ability of crushed limestone particles to flow more easily around the pipe (due to the lack of suction from moisture in the moist Fraser River sand), and therefore, reduce the soil mass existing above the pipe may explain the higher rate of post-peak load reduction (Wijewickreme et. al. 2014).

Even though the number of tests were limited, they are sufficient to draw very useful conclusions regarding the general trends in oblique soil restraint for the two types of soil material tested. Variations of $\mathrm{N}_{\theta}$ with the vertical oblique angle $(\theta)$ derived from the above tests on NPS 16 pipes are illustrated in Fig. 5 for uniformly graded moist sand (MS) and uniformly graded crushed limestone (LS). For both the backfill cases tested, the difference in peak normalized soil restraint is negligible for the two soil types for vertical oblique angles greater than about $35^{\circ}$ to $45^{\circ}$. However, at oblique angles less than about $35^{\circ}$ (more horizontal), the normalized soil restraint for the two materials are considerable different with the crushed limestone producing much higher soil restraint.

\section{Comparisons with other research findings}

Two comparisons are made with previous research related to oblique vertical soil restraint on buried pipelines: the relationship between oblique restraint and inclination angle proposed by Nyman (1984) and the theoretical solution proposed by Hsu (1996).

Nyman (1984) proposed the following expression for relating oblique soil restraint to the angle of inclination, $\alpha$, that varies from $0^{\circ}$ for pure uplift restraint and $90^{\circ}$ for pure lateral restraint: 
$P_{\text {oblique }}=P_{\text {uplift }}\left(1+\frac{0.25 \alpha}{90^{\circ}-0.75 \alpha}\left(\frac{P_{\text {horizontal }}}{P_{\text {uplift }}}-1\right)\right)$

where:

$P_{\text {oblique }}=$ maximum oblique soil restraint

$P_{\text {uplift }}=$ maximum soil restraint in the upward direction

$P_{\text {horizontal }}=$ maximum soil restraint in the horizontal direction

Nyman (1984) based values of $P_{\text {uplift }}$ and $P_{\text {horizontal }}$ on work by Vesic (1971) and Audibert and Nyman (1984), respectively. Rearranging equation [5] to be consistent with the definition of an oblique angle in this paper and recognizing the variation in soil restraint force is the same as a variation in Nq, equation [5] can be expressed as shown in equation [6].

$N_{\theta}=N_{90^{\circ}}\left(1+\frac{22.5^{\circ}-0.25 \theta}{22.5^{\circ}+0.75 \theta}\left(\frac{N_{0^{\circ}}}{N_{90^{\circ}}}-1\right)\right)$

The variation in oblique soil restraint described by equation [6] is compared to the values obtained using currently recommended relationships for $\mathrm{N}_{90^{\circ}}$ and $\mathrm{N}_{0^{\circ}}$ as presented in the 2009 PRCI guidelines and as obtained in the tests (see summary of PRCI and test values in Table 4). As can be seen in Fig. 6, adopting the PRCI 2009 values for $\mathrm{N}_{0^{\circ}}$ and $\mathrm{N}_{90^{\circ}}$ and the trend in equation [6] is generally in good agreement with the experimental data presented herein. Although the data points are limited, curves have been drawn to assist understanding the trends; as such, the actual curve should be used with caution.

Using the measured $\mathrm{N}_{0^{\circ}}$ and $\mathrm{N}_{90^{\circ}}$ values in the trend in equation [6] produces a good match with the MS data point at $\mathrm{N}_{45^{\circ}}$ but the match is worse for the LS data. The poor match with the LS data is not unexpected given the similarity in the normalized soil restraint for the MS and LS tests for angles greater than $35^{\circ}$. 
Nyman (1984) and Hsu (1996) propose a theoretical force equilibrium solution based upon work on inclined plate anchors by Meyerhof (1973), the only difference being the way soil weight within the zone occupied by the top of the pipe is treated (see Fig. 7). Using the approach recommended by Hsu, the oblique force can be determined by finding the value of $\omega$ that minimizes the value of $\mathrm{P}_{\mathrm{u}}$ given by equation [7].

$P_{u}(\omega)=\frac{W+R_{1}(\sin (\phi)-\cos (\phi) \tan (\omega-\phi))}{\cos (\alpha)+\sin (\alpha) \tan (\omega-\phi)}$

where:

$W, R_{l}, \alpha$, and $\omega$ defined in Fig. 7 .

$\phi=$ internal friction angle

$P_{u}=$ maximum soil restraint felt by the pipe during oblique pipe movement

A key challenge in applying equation [7] is related to the computation of the value of force $\mathrm{R}_{1}$, which would also be governed by the appropriate ratio of horizontal soil stress to vertical effective soil stress. Hsu (1996) suggested the use of an "at rest" soil condition for computing $\mathrm{R}_{1}$ for $\alpha$ values less than about $20^{\circ}$, as the amount of lateral soil displacement is small, and the active pressure for larger $\alpha$ values. The use of an "at rest" value also led to calculations of soil restraint consistent with his test results in loose sand with an internal friction angle of $33^{\circ}$, a unit weight of $15.2 \mathrm{kN} / \mathrm{m}^{3}$, and a relative density of $21 \%$.

In the present work, the use of equation [7] with an "at rest" soil stress value for determining $\mathrm{R}_{1}$, theoretical oblique soil restraint values were computed for the soil properties of the UBC MS and LS tests. The results are plotted in Fig. 8, along with the UBC data points. Again, it is noted that the curves have been drawn to assist understanding the trends; as such, the actual curve should be used with caution. 
The theoretical approach from Hsu (1996) compares favorably with the limited UBC data for values of $\theta$ less than about $60^{\circ}$ (or $\alpha>30^{\circ}$ ); the predicted values when $\theta$ is at $90^{\circ}\left(\right.$ or $\alpha=0^{\circ}$ ) have a slightly poorer match with the experimental results. The significant effect of soil friction angle (i.e., difference between sand and limestone soil types) observed in UBC experiments for lower values of $\theta$, where the direction of pipe movement is closer to the horizontal direction, is well captured by the theory. The similarity in oblique soil restraint for the two materials for values of $\theta \geq 35^{\circ}$ also seems to be well captured. Considering that the theory is based on soil block movements along an assumed failure surface, finite element or finite difference numerical analysis that has the ability to model the soil stiffness effects in a continuum basis should be considered for arriving at more robust assessments. The work undertaken by Jung et al. (2016) is an example of the types of finite element analyses that can be employed. It is of relevance to note that the maximum horizontal $\left(\theta=0^{\circ}\right)$, inclined $\left(\theta=45^{\circ}\right)$, and vertical $\left(\theta=90^{\circ}\right)$ soil restraint values for sand generated from their work are also in good agreement with those presented herein. However, it is not appropriate to directly compare these values from Jung et al. (2016) with those presented in this paper since the lateral soil restraint values in their paper are for H/D values greater than 2.

\section{Conclusions}

A series of full-scale pipe soil interaction model tests were undertaken at the University of British Columbia (UBC), Vancouver, British Columbia (BC), Canada, to evaluate the mobilization of soil restraints on buried steel pipelines when subjected to oblique ground displacements. The availability of data from full-scale soil-pipe interaction tests on relatively larger diameter pipes is scarce mainly due to high costs in experimentation and the lack of testing facilities. In this context, the tests conducted at UBC to simulate the performance of an NPS $16(\sim 400-\mathrm{mm}$ outside diameter $)$ pipe specimens buried in two different trench backfill materials (uniformly graded moist sand and uniformly graded crushed limestone) 
provided a unique data set to evaluate soil spring characteristics for numerical modeling of soil-pipe interaction in pipelines subject to oblique ground movements. While the test program was focused on supporting the design of pipeline crossings of reverse faults, the experimental results were sufficient to draw very useful conclusions regarding the variation in oblique soil restraint with relative displacement between the pipe and soil and the general trends for the two types of soil material tested.

The peak normalized oblique soil restraint $\left(\mathrm{N}_{\theta}\right)$ values for $\theta=0^{\circ}$ (horizontal pipe movement) and $\theta=90^{\circ}$ (vertical pipe movement) estimated based on PRCI (2009) using the effective soil friction angle $\left(\phi_{\mathrm{p}}^{\prime}\right)$ values obtained from material-specific laboratory element testing were found to be in reasonable agreement with those directly measured from full-scale soil-pipe interaction chamber testing. The significant effect of $\phi_{p}^{\prime}$ (i.e., difference between sand and limestone soil types) on the magnitude of $\mathrm{N}_{\theta}$ was observed in the experiments for lower values of $\theta$ where the direction of pipe movement is closer to the horizontal direction; on the other hand, the $\mathrm{N}_{\theta}$ was found to be less sensitive to the soil friction angle when the values of $\theta$ increases beyond about $35^{\circ}$.

The tests also revealed that there is a significant reduction of the oblique soil restraint with increasing pipe displacements after reaching a peak $\mathrm{N}_{\theta}$ value, particularly for the cases where pipe displacements occur with $\theta$ values greater than about $35^{\circ}$. The rates of change in oblique soil restraint with pipe displacements after the peak appeared to be related to the particle size distribution of each backfill material. The soils having uniform particles that can potentially "flow" more easily around the pipe (such as the nature of uniform graded crushed limestone) seem to have increased peak load reduction tendency with increasing pipe displacements compared to soils with smaller particles (e.g., moist sand).

The experimental findings for $\mathrm{N}_{\theta}$ compared reasonably well with the theoretical equations recommended by Hsu (1996) particularly for values of $\theta$ less than about $60^{\circ}$ (or when the direction of pipe movement is closer to the horizontal direction. Considering that the theory is based on soil block movements along an 
assumed failure surface, finite element or finite difference numerical analysis that captures the soil stiffness effects in a continuum basis should be considered for arriving at more robust assessments.

\section{References}

Audibert, J.M.E., and Nyman, K.J. 1977. Soil restraint against horizontal motion of pipes. ASCE Journal of the Geotechnical Engineering Division, 103(GT10), 1119-1142.

C-CORE. 2008. Pipeline Integrity for Ground Movement Hazards. Final report prepared for United States Department of Transportation, C-CORE Report R-07-082-459.

Daiyan, N., Kenny, S., Phillips, R., and Popescu, R. 2011. Investigating pipeline-soil interaction under axial-lateral relative movements in sand. Canadian Geotechnical Journal, 48(11), 1683-1695.

Guidelines for the seismic design of oil and gas pipeline systems. Committee on Gas and Liquid Fuel Lifelines; ASCE, New York, 1984.

Guidelines for constructing natural gas and liquid hydrocarbon pipelines in areas subject to landslide and subsidence hazards. report prepared by D. G. Honegger Consulting, C-CORE and SSD Inc. for the Design, Construction \& Operations Technical Committee of Pipeline Research Council International Inc.; PRCI 2009, Catalog No. L52292(V).

Guo, P. J. 2005. Numerical modeling of pipe-soil interaction under oblique loading. Journal of Geotechnical and Geoenvironmental Engineering, 131(2), 260-268.

Honegger, D. G., and Nyman, D. J. 2004. Guidelines for the seismic design and assessment of natural gas and liquid hydrocarbon pipelines. Report prepared for Pipeline Design, Construction \& Operations Technical Committee of Pipeline Research Council International, Inc., PR-268-9823.

Hsu, T. W. 1996. Soil restraint against oblique motion of pipelines in sand. Canadian Geotechnical Journal, 33, 180-188. 
Hsu, T.W., Chen, Y.J., and Hung, W.C. 2006. Soil restraint to oblique movement of buried pipes in dense sand. Journal of Transportation Engineering 132(2): 175-181.

Hsu, T.W., Chen, Y.J., and Wu, C.Y. 2001. Soil friction restraint of oblique pipelines in loose sand. Journal of Transportation Engineering 127(1): 82-87.

Jung, J.K., O'Rourke, T., and Argyrou, C. 2016. Multi-Directional Force-Displacement Response of Underground Pipe in Sand. Canadian Geotechnical Journal. doi: 10.1139/cgj-2016-0059.

Karimian, H. 2006. Response of Buried Steel Pipelines subjected to Longitudinal and Transverse Ground Movement, Ph.D. Thesis, University of British Columbia.

Meyerhof, G. 1973. Uplift resistance of inclined anchors and piles. Proceeding of the 8th International Conference on Soil Mechanics and Foundation Engineering, Moscow, 2, 167-172.

Monroy, M. 2013. Soil restraints on steel buried pipelines crossing active seismic faults. Ph.D. Thesis, University of British Columbia, Vancouver, Canada.

Nyman, K. J. 1984. Soil response Against Oblique Motion of Pipes. Journal of Transpotation Engineering. 110, 190-202.

O'Rourke, T.D., Jung, J.K., and Argyrou, C. 2016. Underground pipeline response to earthquake-induced ground deformation. Soil Dynamics and Earthquake Engineering. doi: http://dx.doi.org/10.1016/j.soildyn.2016.09.008.

O’Rourke, T.D., Jezerski, J.M., Olson, N. A., Bonneau, A.L., Palmer, M.C., Stewart, H.E., O’Rourke, M. J., and Abdoun, T. 2008. Geotechnics of pipeline system response to earthquakes, Proceedings of the Geotechnical Earthquake Engineering and Soil Dynamics IV, Sacramento, California, GSP(181). 
Paulin, M.J., Phillips, R., Clark, J.I., Trigg, A., and Konuk, I. 1998. A full-scale investigation into pipeline/soil interaction. Proceedings, International Pipeline Conference, Calgary, AB, ASME, 779-788.

Prisco, C., and Galli, A. 2006. Soil-pipe interaction under monotonic and cyclic loads: experimental and numerical modelling. Proceedings of the $1^{\text {st }}$ Euro mediterranean symposium in advances on geomaterials and structures, Hammamet, Tunisia , 755-761.

Saiyar, M., Ni, P., Take, W.A., and Moore, I.D. 2016. Response of pipelines of differing flexural stiffness to normal faulting. Géotechnique 66(4): 275-286. doi: 10.1680/jgeot.14.P.175.

Trautmann, C.H., and O’Rourke, T.D. 1985. Lateral force displacement response of buried pipe. ASCE Journal of Geotechnical Engineering, 111(9), 1077-1092.

Wijewickreme, D., Karimian, H., and Honegger, D. 2009. Response of buried steel pipelines subject to relative axial soil movement. Canadian Geotechnical Journal, 46(7), 735-752.

Wijewickreme, D., Monroy, M., Nyman, D.J., and Honegger, D.G. 2014. Response of Buried Pipelines Subjected to Ground Displacements Under Different Trench Backfill Conditions, 10th U.S. National Conference on Earthquake Engineering (10NCEE) Conference, EERI, Anchorage, Alaska, USA, July 21-25, 2014.

Yimsiri, S., Soga, K., Yoshizaki, K., Dasari, G.R., and O’Rourke, T.D. 2004.Lateral and upward soilpipeline interactions in sand for deep embedment conditions. ASCE Journal of Geotechnical and Geoenvironmental Engineering, 130 (8).

Vesic, A.S. 1971. Breakout resistance of objects embedded in ocean bottom, Journal of the Soil Mechanics and Foundation Engineering Division, ASCE, 97 (SM9), pp.1183-1205. 


\section{List of Figures}

Table 1: Summary of parameters related to test soil backfill materials

Table 2: Details of soil restraint tests

Table 3: Summary of soil restraint test results

Table 4: Summary of peak normalized soil restraint derived soil restraint testing. 


\section{List of Figure Captions}

Fig.1. General view of the Advanced Soil Pipe Interaction Research (ASPIRe ${ }^{\mathrm{TM}}$ ) facility at UBC.

Fig. 2. Configuration of the ASPIRe ${ }^{\mathrm{TM}}$ facility to study vertical oblique soil restraints.

Fig. 3. Grain size distribution of trench backfill materials used in the present study.

Fig. 4. Normalized oblique lateral soil restraint $\left(\mathrm{N}_{\theta}\right)$ versus displacement NPS16 pipe - H/D=1.6: (a) Test No. 1, $\theta=0^{\circ}$, Moist sand backfill; (b) Test No. 2, $\theta=45^{\circ}$, Moist sand backfill; (c) Test No. 3, $\theta=90^{\circ}$, Moist sand backfill; (d) Test No. 4, $\theta=0^{\circ}$, Limestone backfill; (e) Test No. 5, $\theta=35^{\circ}$, Limestone backfill; (f) Test No. 6, $\theta=45^{\circ}$, Limestone backfill; (g) Test No. 7, $\theta=90^{\circ}$, Limestone backfill.

Fig. 5. Variation of normalized oblique lateral soil restraint $\left(\mathrm{N}_{\theta}\right)$ versus vertical oblique angle $(\theta)$ : NPS16 pipe $-\mathrm{H} / \mathrm{D}=1.6$ (Note: $\mathrm{MS}=$ Moist sand backfill; $\mathrm{LS}=$ Limestone backfill).

Fig. 6. Comparison of normalized oblique lateral soil restraint $\left(\mathrm{N}_{\theta}\right)$ versus vertical oblique angle $(\theta)$ with data trend suggested by Nyman (1984) (Note: MS = Moist sand backfill; LS = Limestone backfill).

Fig. 7. Equilibrium formulations of Nyman (1984) and Hsu (1996).

Fig. 8. Comparison of theoretical solutions for normalized oblique lateral soil restraint $\left(\mathrm{N}_{\theta}\right)$ versus vertical oblique angle $(\theta)$ with data from testing at UBC (Note: MS = Moist sand backfill; LS = Limestone backfill). 


\section{$\underline{\text { List of Figures }}$}

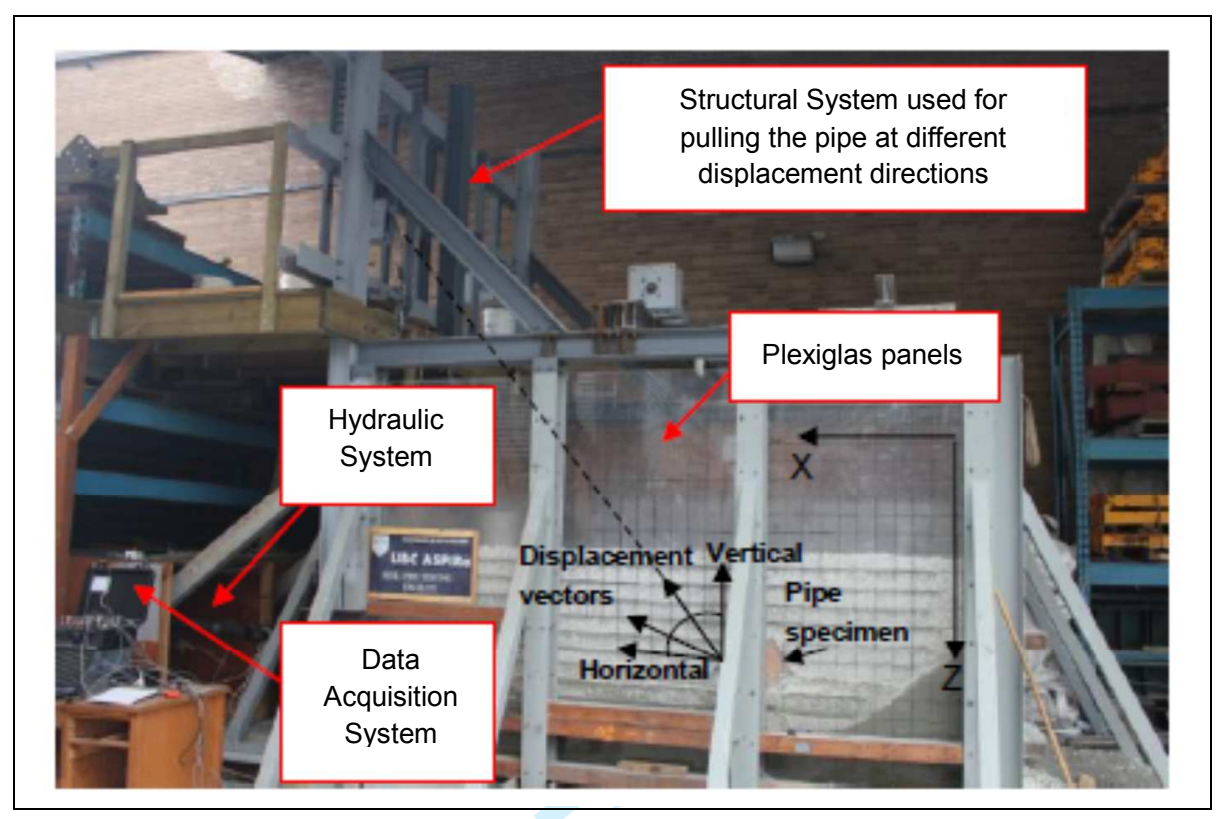

Fig.1. General view of the Advanced Soil Pipe Interaction Research (ASPIRe ${ }^{\mathrm{TM}}$ ) facility at UBC. 


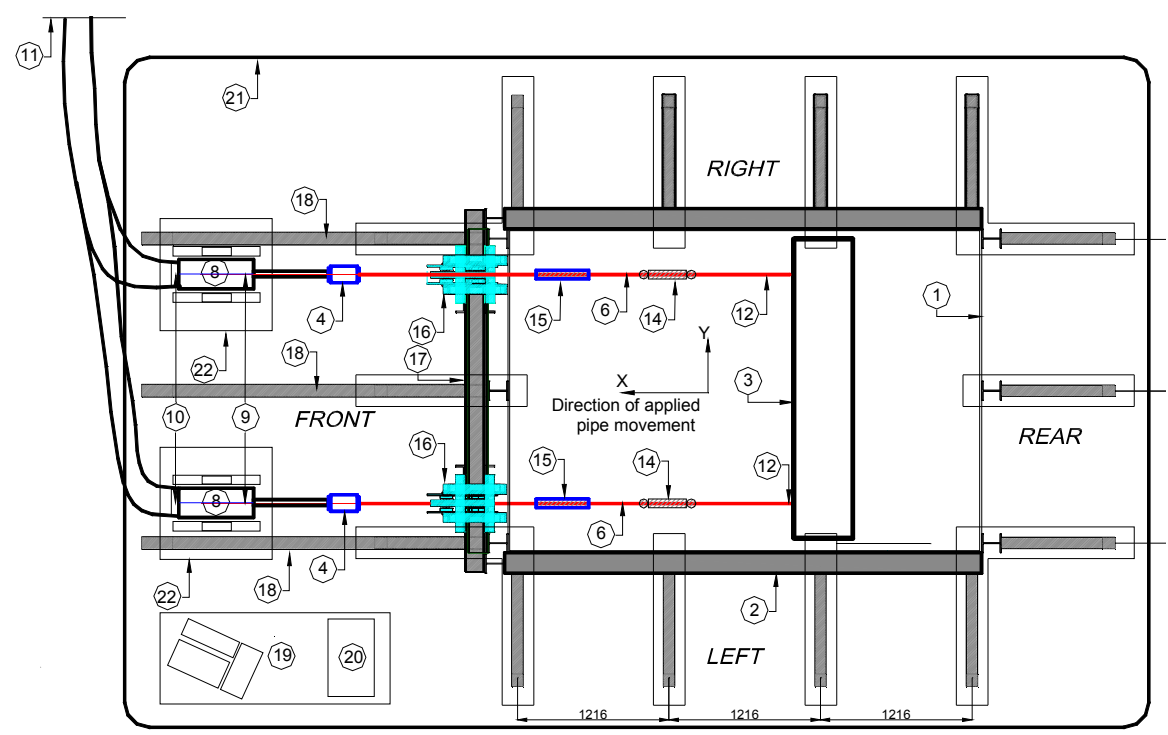

(a) Plan view

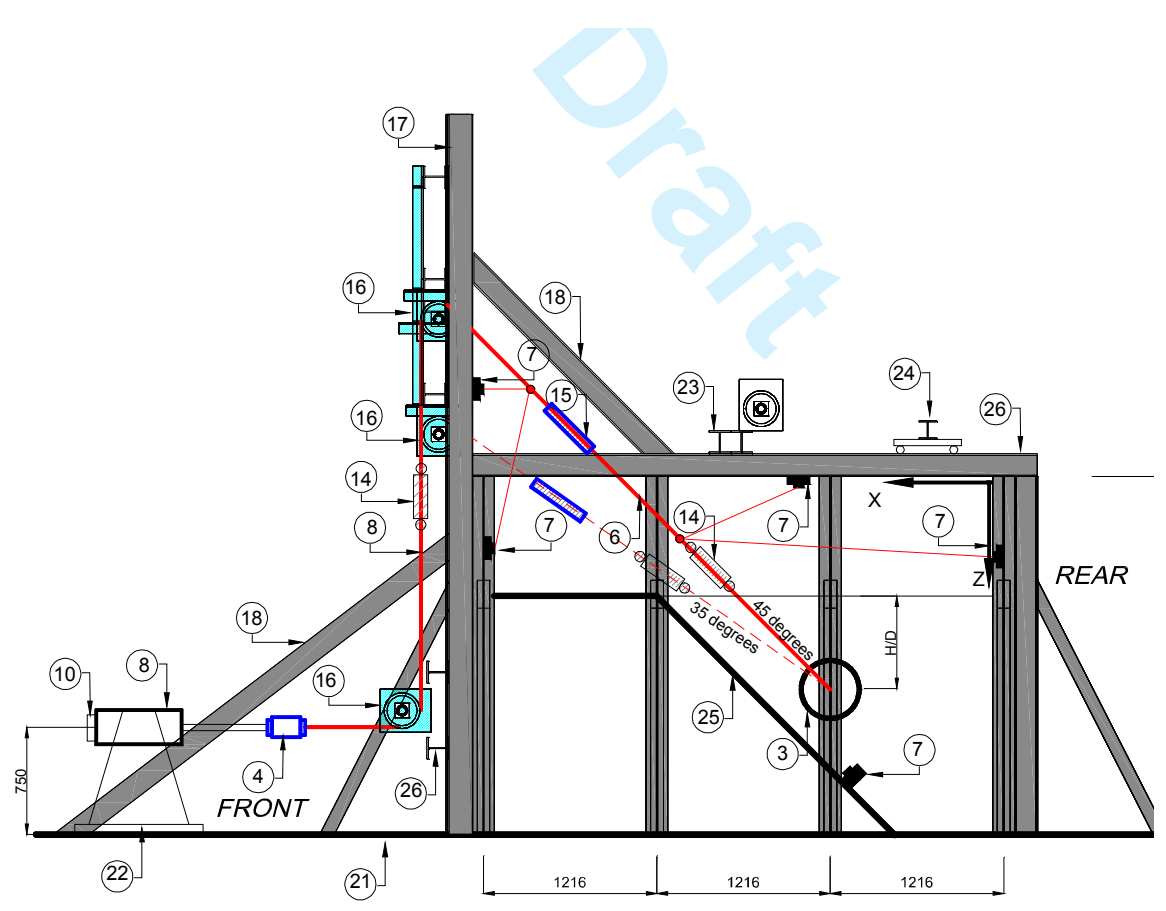

1. Soil chamber

2. Plexi-glass panel

3. Pipe specimen

4. Load cell for lateral soil restraint

5. Load cell for axial soil restraint

6. $25 \mathrm{~mm}$ steel cables

7. String potentiometer

8. Hydraulic actuator system

9. VDT

10. Servo controller

11. To hydraulic power

12. Steel cable to pipe connector

13. Reaction steel plate

14. Load cell for oblique soil restraint and inclinometer

15. Sheave system for oblique pulling

16. Vertical steel frame system

17. Steel brace for lateral stiffness

18. Data acquisition system \& computer

19. Control System

20. -Steel foundation pad

21. Hydraulic system for vertical pulling

22. Sheave system for vertical pulling

23. Crane

24. Collar steel beam

25. Trench wall (1:1 slope)

(b) Lateral view

Fig. 2. Configuration of the ASPIRe ${ }^{\mathrm{TM}}$ facility to study vertical oblique soil restraints 


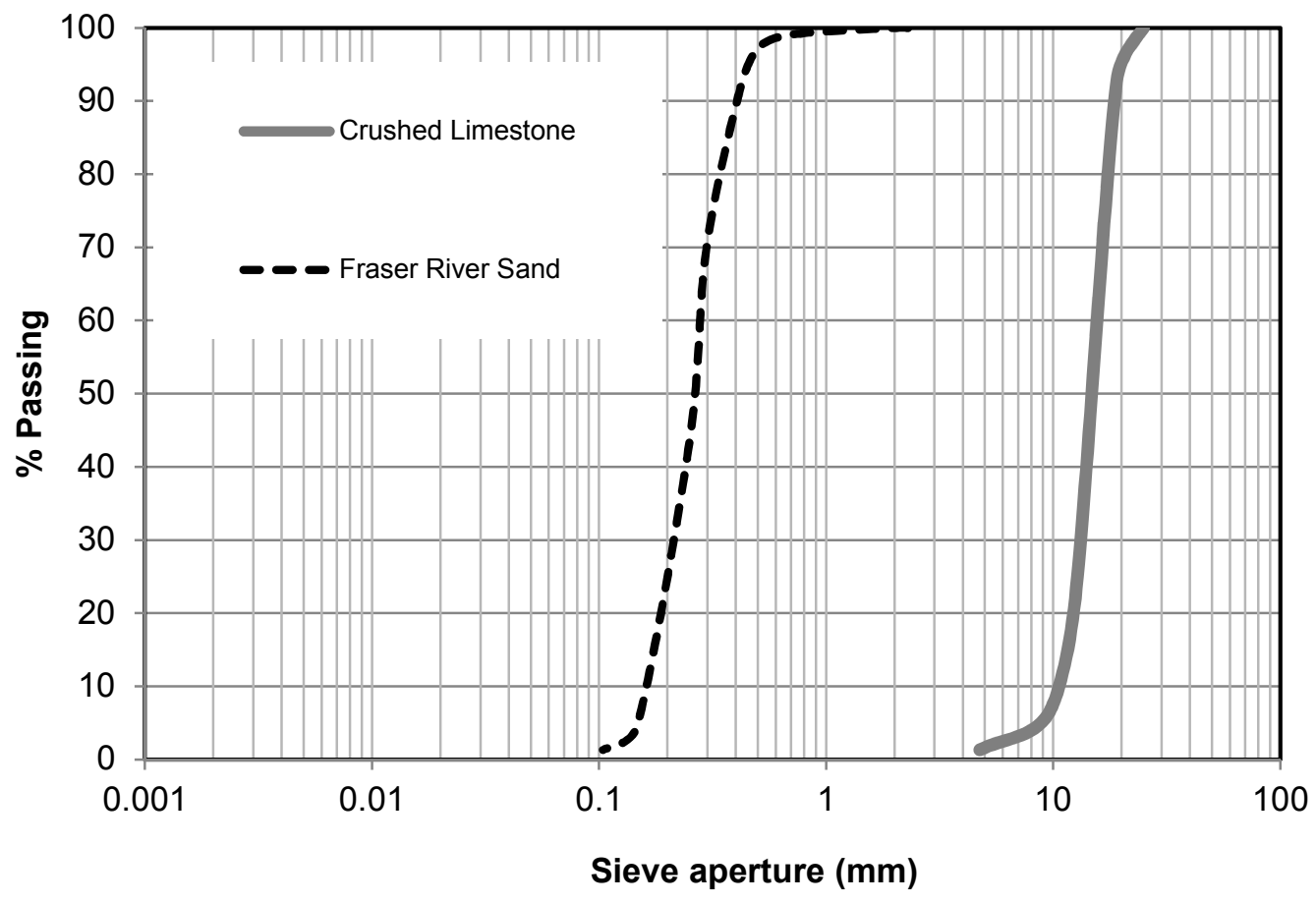

Fig. 3. Grain size distribution of trench backfill materials used in the present study. 
(a)

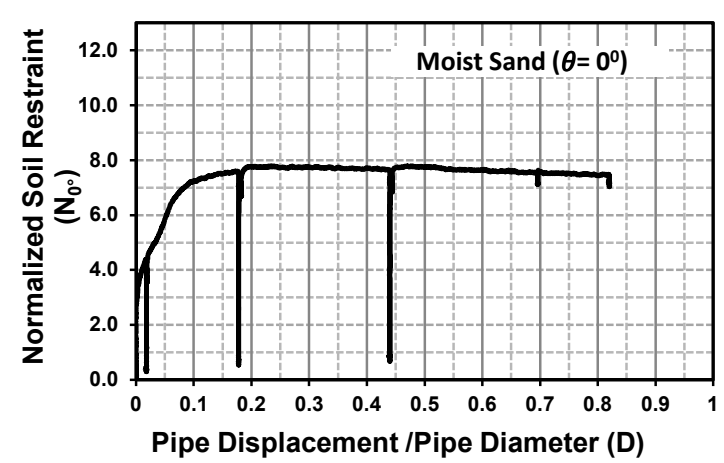

(c)

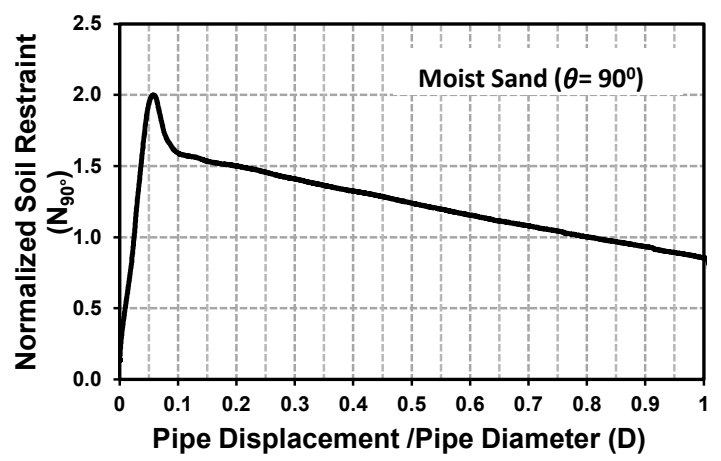

(e)

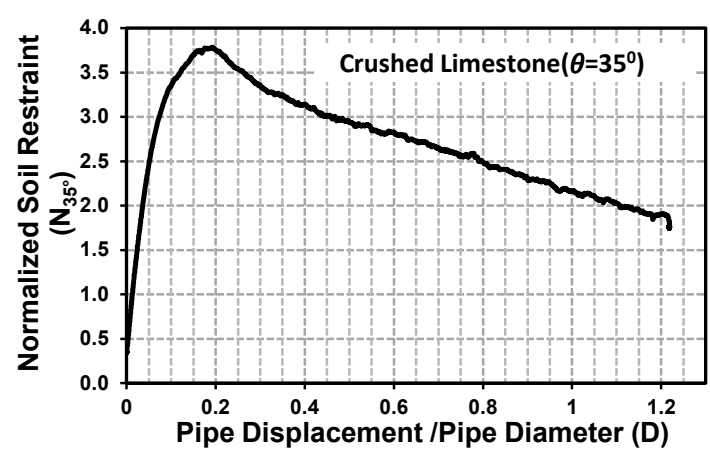

(g)

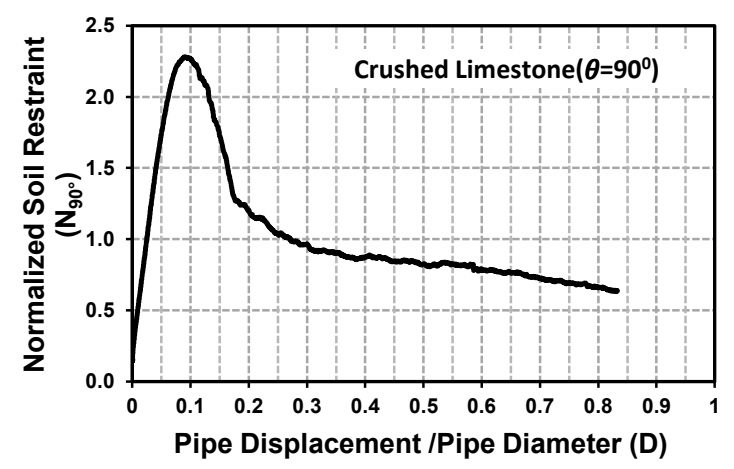

(b)

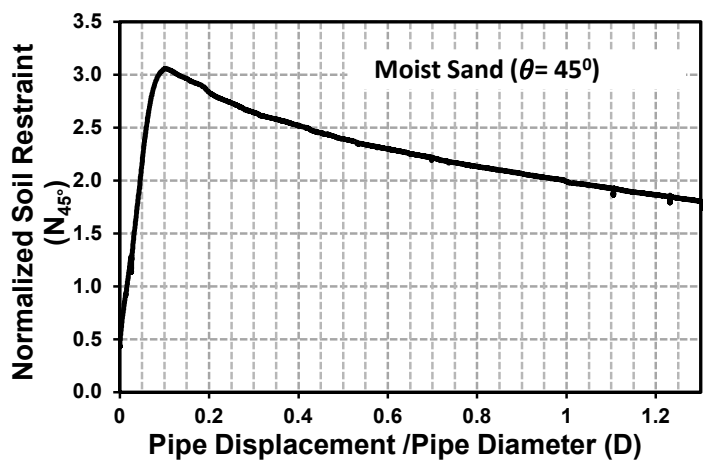

(d)

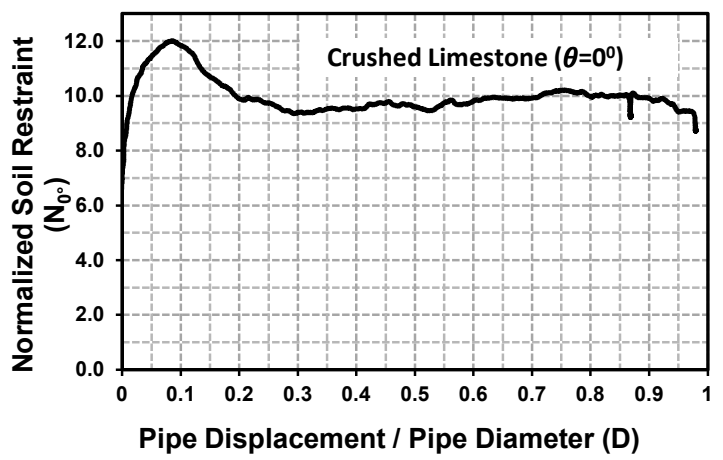

(f)

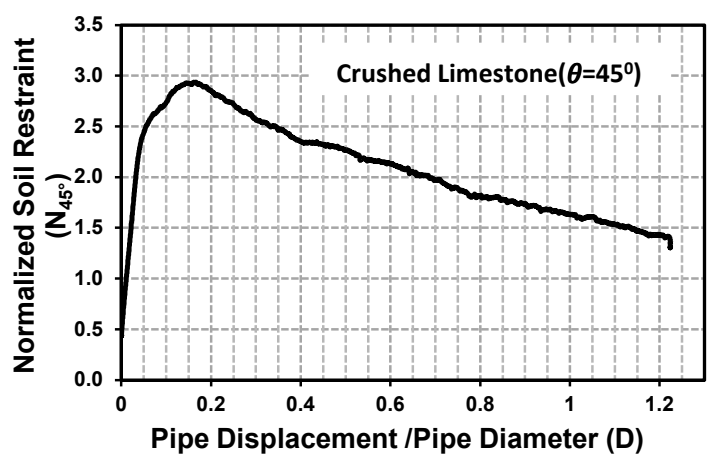

Fig. 4. Normalized oblique lateral soil restraint $\left(\mathrm{N}_{\theta}\right)$ versus displacement NPS16 pipe - H/D=1.6: (a) Test No. 1, $\theta=0^{\circ}$, Moist sand backfill; (b) Test No. 2, $\theta=45^{\circ}$, Moist sand backfill; (c) Test No. 3, $\theta=90^{\circ}$, Moist sand backfill; (d) Test No. 4, $\theta=0^{\circ}$, Limestone backfill; (e) Test No. 5, $\theta=35^{\circ}$, Limestone backfill; (f) Test No. 6, $\theta=45^{\circ}$, Limestone backfill; (g) Test No. 7, $\theta=90^{\circ}$, Limestone backfill. 


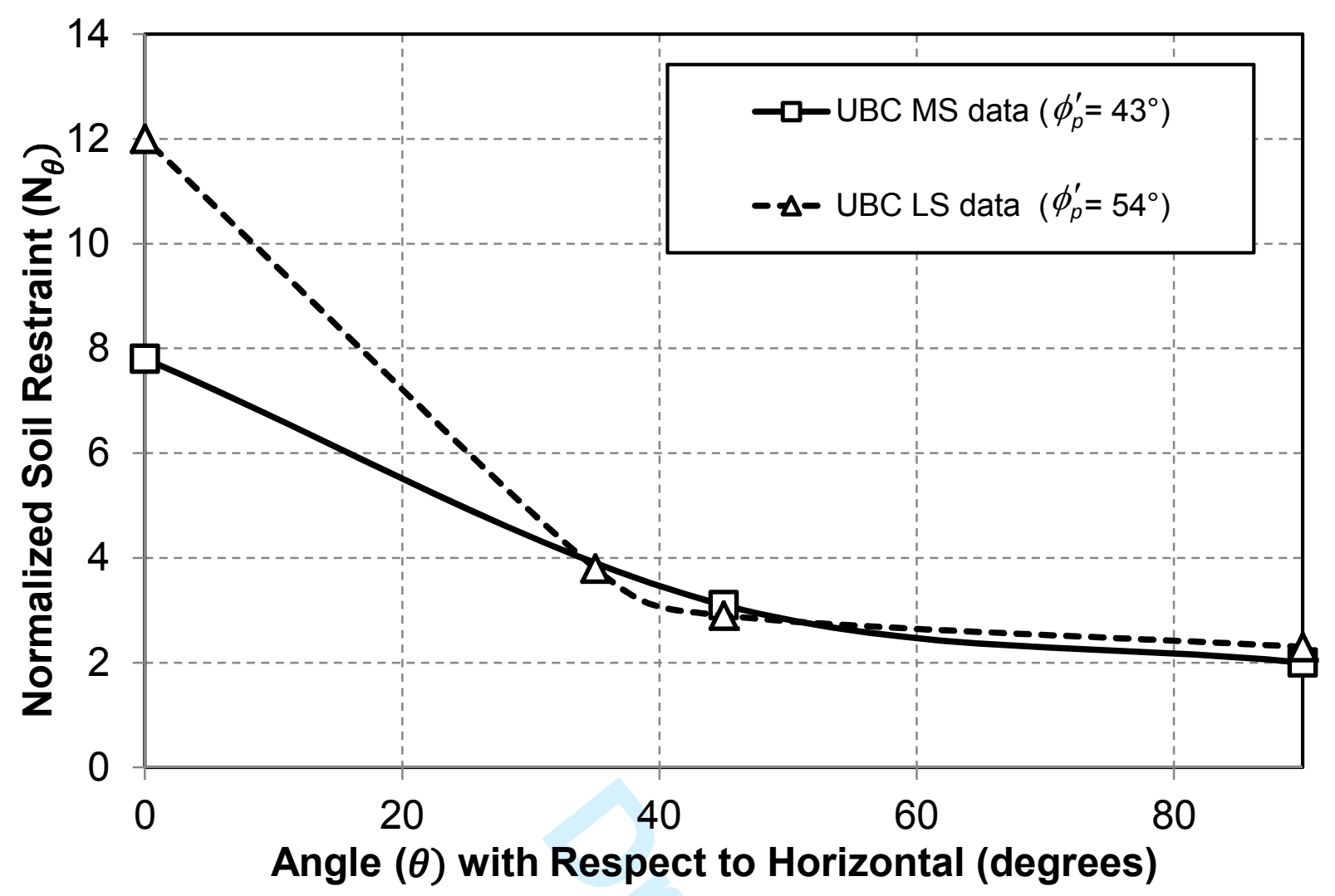

Fig. 5. Variation of normalized oblique lateral soil restraint $\left(\mathrm{N}_{\theta}\right)$ versus vertical oblique angle $(\theta)$ : NPS16 pipe $-\mathrm{H} / \mathrm{D}=1.6$ (Note: MS = Moist sand backfill; $\mathrm{LS}=$ Limestone backfill). 


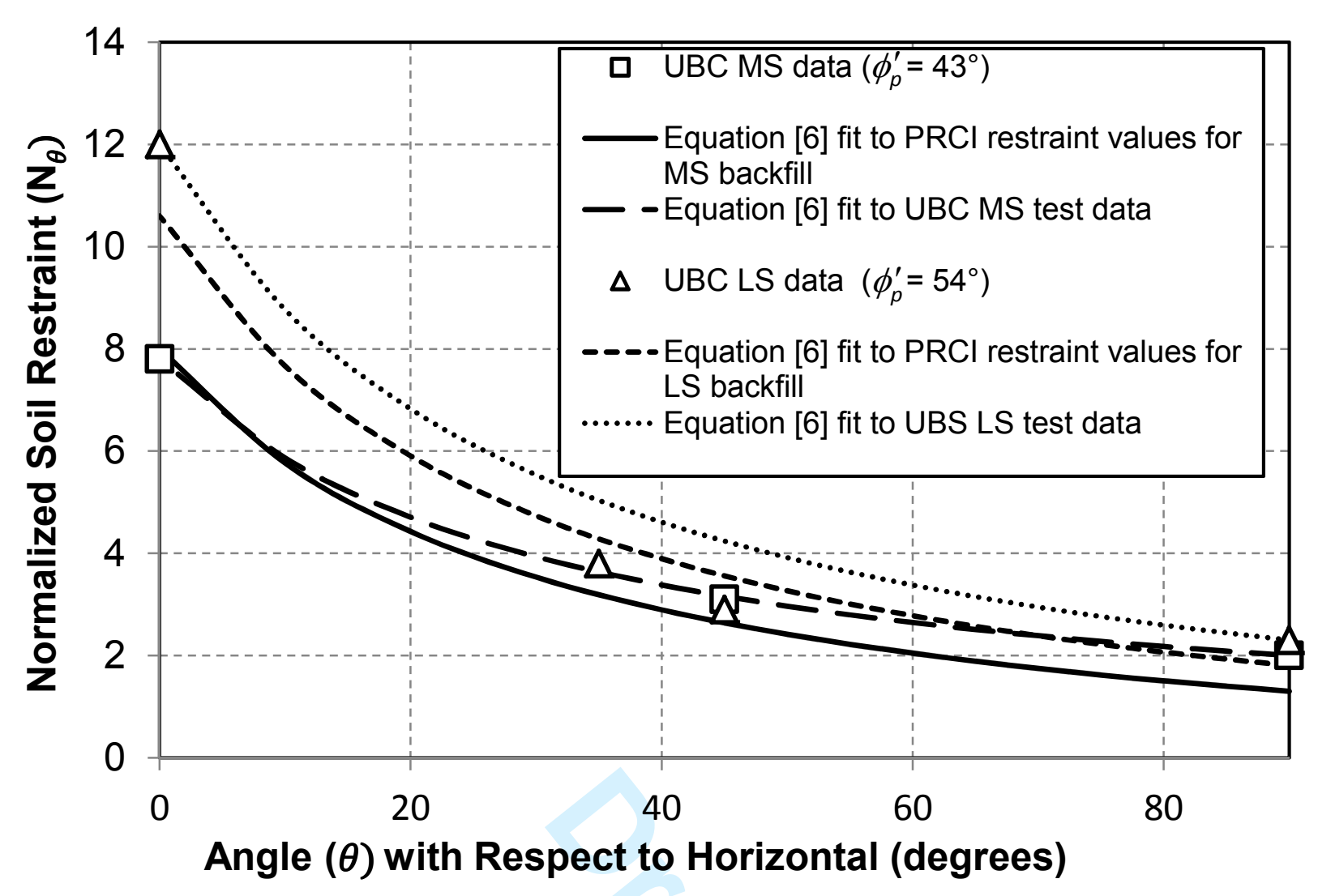

Fig. 6. Comparison of normalized oblique lateral soil restraint $\left(\mathrm{N}_{\theta}\right)$ versus vertical oblique angle $(\theta)$ with data trend suggested by Nyman (1984) (Note: MS = Moist sand backfill; LS = Limestone backfill). 

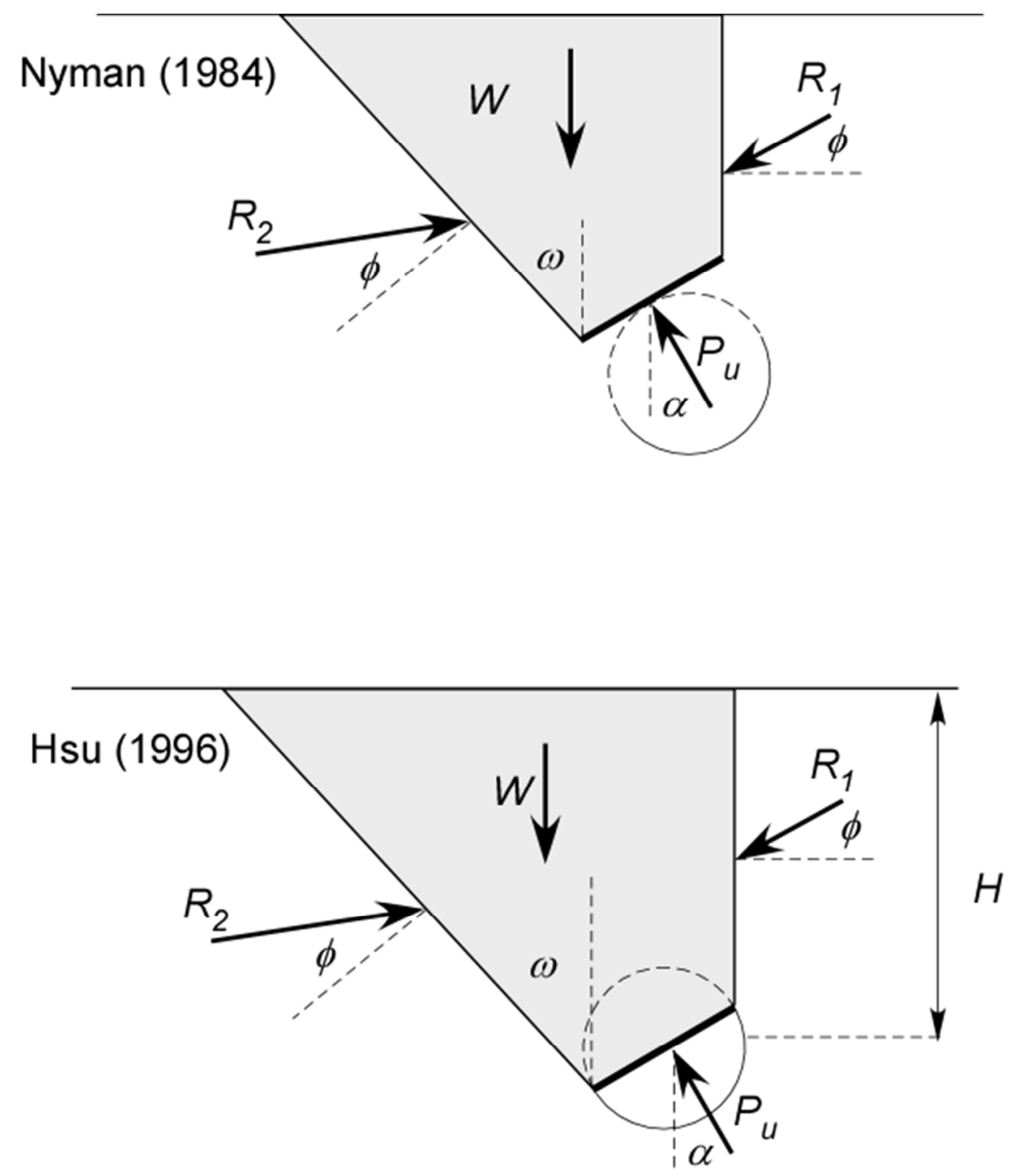

$$
\begin{aligned}
& P_{u} \sin (\alpha)-R_{2} \cos (\omega-\phi)=-R_{1} \cos (\phi) \\
& P_{u} \cos (\alpha)+R_{2} \sin (\omega-\phi)=W+R_{1} \sin (\phi)
\end{aligned}
$$

Fig. 7. Equilibrium formulations of Nyman (1984) and Hsu (1996) 


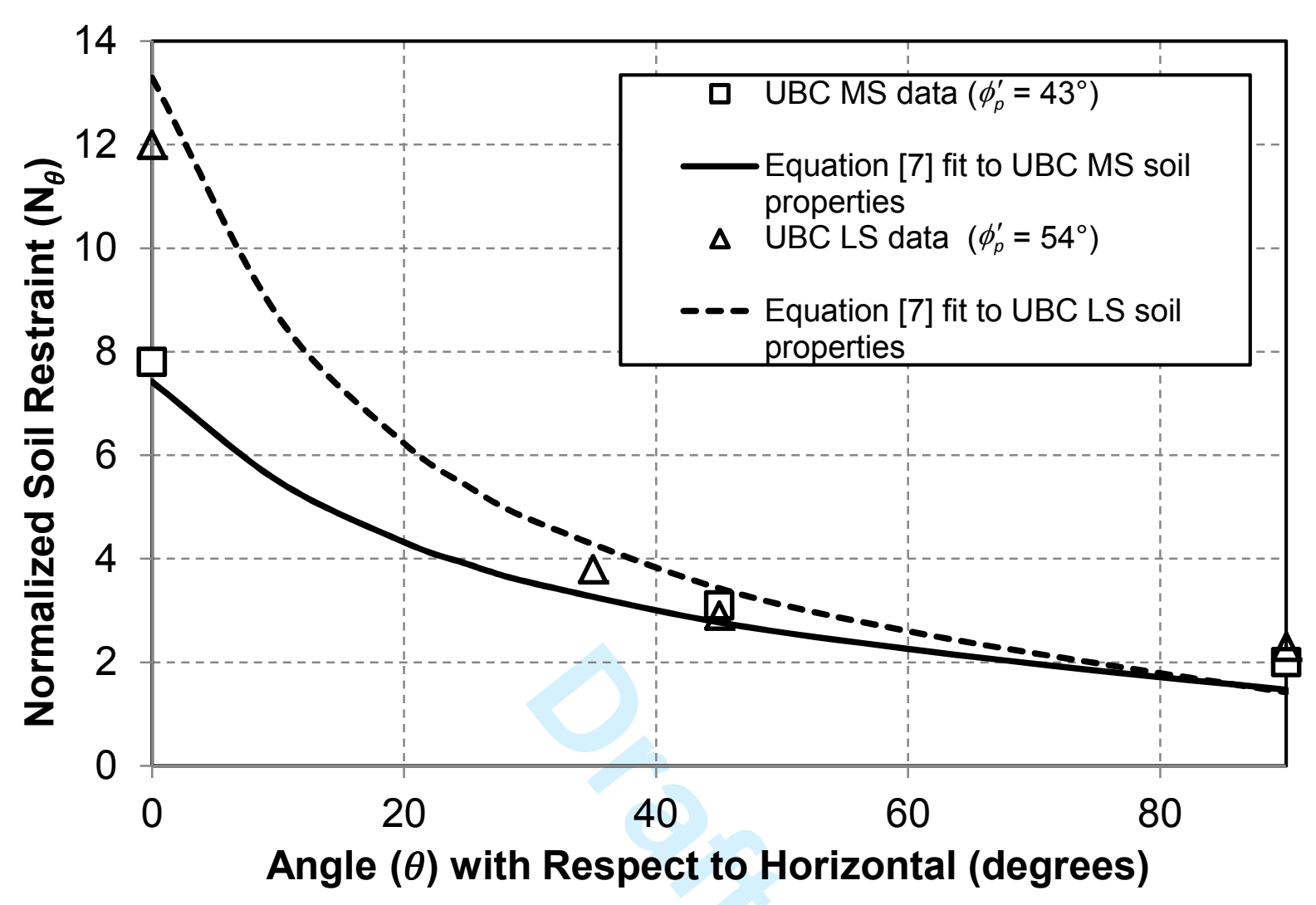

Fig. 8. Comparison of theoretical solutions for normalized oblique lateral soil restraint $\left(\mathrm{N}_{\theta}\right)$ versus vertical oblique angle $(\theta)$ with data from testing at UBC (Note: MS = Moist sand backfill; LS = Limestone backfill). 


\section{List of Tables}

Table 1: Summary of parameters related to test soil backfill materials

\begin{tabular}{lccc}
\hline & Fraser River sand & Crushed Limestone & Road Mulch \\
\hline $\begin{array}{l}\text { Average dry density } \\
\left(\mathrm{kg} / \mathrm{m}^{3}\right)\end{array}$ & 1,600 & 1,700 & 1,800 \\
\hline $\begin{array}{l}\text { Average moisture } \\
\text { content }(\%)\end{array}$ & 3 to 4 & Approx. $<4 \%$ & Approx. $<4 \%$ \\
\hline $\begin{array}{l}\text { Internal peak friction } \\
\text { angle } \phi^{\prime} \text { p }\end{array}$ & $43^{\circ}$ & $54^{\circ}$ & $49^{\circ}-59^{\circ}$ \\
\hline Dilation angle $\psi$ & $12^{\circ}$ & $16^{\circ}$ & Not available. \\
\hline
\end{tabular}

$\psi$ values corresponding with the density and effective confining stress ranges used in the soil restraint testing.

Table 2: Details of soil restraint tests

\begin{tabular}{|c|c|c|c|c|c|c|}
\hline $\begin{array}{l}\text { Test } \\
\text { No. }\end{array}$ & Pipe & $\begin{array}{l}\text { Trench } \\
\text { details }\end{array}$ & $\begin{array}{l}\text { H/D } \\
\text { ratio }\end{array}$ & $\begin{array}{c}\text { Pulling } \\
\text { oblique } \\
\text { angle }(\theta) \\
\text { w.r.t } \\
\text { horizontal }\end{array}$ & $\begin{array}{c}\text { Backfill } \\
\text { (moisture } \\
\text { content) }\end{array}$ & $\begin{array}{c}\text { Average } \\
\text { backfill dry } \\
\text { density } \\
\left(\mathbf{k g} / \mathbf{m}^{3}\right)\end{array}$ \\
\hline 1 & NPS16 & $\begin{array}{c}\text { No } \\
\text { Trench }\end{array}$ & 1.6 & $0^{\circ}$ & Sand (4\%) & 1,600 \\
\hline 2 & NPS16 & $\begin{array}{l}\text { Trench } \\
\text { @ } 45^{\circ}\end{array}$ & 1.6 & $45^{\circ}$ & Sand $(4 \%)$ & 1,600 \\
\hline 3 & NPS16 & $\begin{array}{l}\text { No } \\
\text { Trench }\end{array}$ & 1.6 & $90^{\circ}$ & Sand $(4 \%)$ & 1,600 \\
\hline 4 & NPS16 & $\begin{array}{l}\text { No } \\
\text { Trench }\end{array}$ & 1.6 & $0^{\circ}$ & $\begin{array}{c}\text { Crushed } \\
\text { Limestone (4\%) }\end{array}$ & 1,700 \\
\hline 5 & NPS16 & $\begin{array}{l}\text { Trench } \\
@ 45^{\circ}\end{array}$ & 1.6 & $35^{\circ}$ & $\begin{array}{c}\text { Crushed } \\
\text { Limestone (4\%) }\end{array}$ & 1,700 \\
\hline 6 & NPS16 & $\begin{array}{l}\text { Trench } \\
@ 45^{\circ}\end{array}$ & 1.6 & $45^{\circ}$ & $\begin{array}{c}\text { Crushed } \\
\text { Limestone (4\%) }\end{array}$ & 1,700 \\
\hline 7 & NPS16 & $\begin{array}{l}\text { No } \\
\text { Trench }\end{array}$ & 1.6 & $90^{\circ}$ & $\begin{array}{c}\text { Crushed } \\
\text { Limestone (4\%) }\end{array}$ & 1,700 \\
\hline
\end{tabular}


Table 3: Summary of soil restraint test results

\begin{tabular}{cccccc}
\hline $\begin{array}{c}\text { Test } \\
\text { No. }\end{array}$ & $\begin{array}{c}\text { Oblique } \\
\text { angle }(\theta) \\
\text { w.r.t } \\
\text { horizontal }\end{array}$ & $\begin{array}{c}\text { H/D } \\
\text { ratio }\end{array}$ & $\begin{array}{c}\text { Backfill } \\
\left(\phi_{\mathrm{p}}^{\prime}=\text { Effective peak friction }\right. \\
\text { angle; } \psi=\text { Dilation angle })\end{array}$ & $\begin{array}{c}\text { Peak } \\
\text { normalized } \\
\text { soil restraint }\end{array}$ & $\begin{array}{c}\text { Pipe } \\
\text { displacement } \\
\text { at peak }\end{array}$ \\
\hline 1 & $0^{\circ}$ & 1.6 & Sand $\left(\phi_{\mathrm{p}}^{\prime}=43^{\circ} ; \psi=12^{\circ}\right)$ & 7.8 & $0.25 \mathrm{D}$ \\
\hline 2 & $45^{\circ}$ & 1.6 & Sand $\left(\phi_{\mathrm{p}}^{\prime}=43^{\circ} ; \psi=12^{\circ}\right)$ & 3.0 & $0.10 \mathrm{D}$ \\
\hline 3 & $90^{\circ}$ & 1.6 & Sand $\left(\phi_{\mathrm{p}}^{\prime}=43^{\circ} ; \psi=12^{\circ}\right)$ & 2.0 & $0.05 \mathrm{D}$ \\
\hline 4 & $0^{\circ}$ & 1.6 & $\begin{array}{c}\text { Crushed Limestone } \\
\left(\phi_{\mathrm{p}}^{\prime}=54^{\circ} ; \psi=16^{\circ}\right)\end{array}$ & 12.0 & $0.10 \mathrm{D}$ \\
\hline 5 & $35^{\circ}$ & 1.6 & $\begin{array}{c}\text { Crushed Limestone } \\
\left(\phi_{\mathrm{p}}^{\prime}=54^{\circ} ; \psi=16^{\circ}\right)\end{array}$ & 3.8 & $0.18 \mathrm{D}$ \\
\hline 6 & $45^{\circ}$ & 1.6 & $\begin{array}{c}\text { Crushed Limestone } \\
\left(\phi_{\mathrm{p}}^{\prime}=54^{\circ} ; \psi=16^{\circ}\right)\end{array}$ & 2.9 & $0.15 \mathrm{D}$ \\
\hline 7 & $90^{\circ}$ & 1.6 & $\begin{array}{l}\text { Crushed Limestone } \\
\left(\phi_{\mathrm{p}}^{\prime}=54^{\circ} ; \psi=16^{\circ}\right)\end{array}$ & 2.3 & $0.10 \mathrm{D}$ \\
\hline
\end{tabular}

Table 4. Summary of peak normalized soil restraint derived soil restraint testing.

\begin{tabular}{lcccc}
\hline & Oblique & \multicolumn{2}{c}{$\begin{array}{c}\text { Peak normalized soil } \\
\text { restraint }\end{array}$} \\
\cline { 4 - 5 } Backfill type & $\boldsymbol{\phi}_{\mathbf{p}}^{\prime}$ & $\begin{array}{c}\text { angle }(\boldsymbol{\theta}) \\
\text { w.r.t }\end{array}$ & $\begin{array}{c}\text { From } \\
\text { full-scale } \\
\text { horizontal } \\
\text { laboratory } \\
\text { testing }\end{array}$ & $\begin{array}{c}\text { Predicted } \\
\text { using } \\
\text { PRCI } \\
\mathbf{( 2 0 0 9 )}\end{array}$ \\
\hline Moist Sand & $43^{\circ}$ & $0^{\circ}$ & 7.8 & 8.0 \\
& & $90^{\circ}$ & 2.0 & 1.3 \\
\hline Crushed Limestone & $54^{\circ}$ & $0^{\circ}$ & 12.0 & $10.6^{(1)}$ \\
& & $90^{\circ}$ & 2.3 & 1.8 \\
\hline
\end{tabular}

Note (1): Estimated based on linear extrapolation of PRCI (2009) guidelines. 